\title{
STUDI ANALISIS KADAR BILIRUBIN TERHADAP LAMA WAKTU KONSUMSI OBAT ANTI TUBERKULOSIS (OAT) PADA PENDERITA TUBERKULOSIS PARU
}

\section{Study of analysis bilirubin concentration based on consumption time of Anti tuberculosis drug in pulmonary tuberculosis patients}

\author{
Cindy Yunita ${ }^{1}$, Novi Utami Dewi ${ }^{2}$ \\ ${ }^{1}$ Jurusan Analis Kesehatan Poltekkes Kemenkes Makassar \\ ${ }^{2}$ Jurusan Analis Kesehatan Poltekkes Kemenkes Bandung
}

Koresponden: noviutami@ poltekkes-mks.ac.id

\begin{abstract}
ABSTRAK
Tuberkulosis merupakan penyakit yang disebabkan oleh berbagai strain mikobakteria, umumnya Mycobacterium tuberculosis. Pengobatan penyakit tuberkulosis paru yang dilakukan selama berbulan-bulan ini, dikhawatirkan dapat mengganggu beberapa fungsi organ terutama organ hati sehingga dapat mempengaruhi mekanisme kerja hati. Tujuan penelitian ini adalah untuk mengetahui gambaran kadar bilirubin terhadap lama waktu konsumsi obat anti tuberkulosis (OAT) pada penderita tuberkulosis paru. Penelitian ini merupakan penelitian analitik dengan teknik pengambilan sampel purposive sampling. Besar sampel pada penelitian ini adalah 28 sampel. Spesimen serum dari sampel penelitian diperiksa dengan metode spektrofotometri. Penelitian ini dilaksanakan di laboratorium RSUD Labuang Baji Makassar pada tanggal 22 Februari s/d 09 Mei 2018. Hasil penelitian yaitu kadar bilirubin total pada bulan kedua dan kelima kadarnya normal (100\%), terjadi peningkatan kadar bilirubin pada bulan ketiga $(28,57 \%)$ dan bulan keempat $(14,29 \%)$, kadar bilirubin direk pada bulan kedua sampai dengan bulan keempat terjadi peningkatan $(28,57 \%)$ dan bulan kelima $(14,29 \%)$ serta kadar bilirubin indirek bulan kedua dan bulan kelima normal (100\%) dan terjadi peningkatan pada bulan ketiga dan bulan keempat (14,29\%). Disarankan dilakukan penelitian lanjutan untuk menganalisis fungsi hati dengan pemeriksaan atau metode yang lebih spesifik dan menambah jumlah sampel pemeriksaan.Untuk klinisi sebaiknya terhadap penderita tuberkulosis diperiksa fungsi hatinya termasuk kadar bilirubin sebelum pengobatan dimulai dan setiap bulan pengobatan sebagai kontrol sehingga efek samping OAT dapat cepat diketahui dan ditangani dengan baik.
\end{abstract}

Kata Kunci : Bilirubin, Lama Konsumsi, OAT, Tuberkulosis

\section{PENDAHULUAN}

TB adalah penyakit menular yang disebabkan oleh bacillus Mycobacterium tuberculosis. Ini biasanya mempengaruhi paru-paru (TB paru) tetapi juga dapat mempengaruhi tempat lain (TB luar paru). Penyakit ini menyebar ketika orang yang sakit TB paru mengeluarkan bakteri ke udara, misalnya dengan batuk. Pada 2015, diperkirakan ada 10,4 juta kasus TB di 
seluruh dunia, di mana 5,9 juta $(56 \%)$ pria, 3,5 juta $(34 \%)$ wanita dan 1,0 juta (10\%) pada anak-anak. Orang yang hidup dengan HIV menyumbang 1,2 juta $(11 \%)$ dari semua kasus TB baru. Enam negara menyumbang $60 \%$ dari kasus baru: India, Indonesia, Cina, Nigeria, Pakistan dan Afrika Selatan.('TB Global Report 2016 WHO', no date)

Secara global pada tahun 2016 terdapat 10,4 juta kasus insiden TBC (CI 8,8 juta - 12, juta) yang setara dengan 120 kasus per 100.000 penduduk. Lima negara dengan insiden kasus tertinggi yaitu India, Indonesia, China, Philipina, dan Pakistan. Sebagian besar estimasi insiden TBC pada tahun 2016 terjadi di Kawasan Asia Tenggara $(45 \%)$ dimana Indonesia merupakan salah satu di dalamnya dan $25 \%$ nya terjadi di kawasan Afrika.Jumlah kasus baru TB di Indonesia sebanyak 420.994 kasus pada tahun 2017 (data per 17 Mei 2018). Badan kesehatan dunia menetapkan standar keberhasilan pengobatan sebesar 85\%. Angka keberhasilan pada tahun 2017 sebesar 87,8\% (data per 21 Mei 2018).(Kementerian Kesehatan RI, 2018)

Provinsi Sulawesi Selatan, berdasarkan data yang diperoleh dari Bidang Bina P2PL Dinas Kesehatan Kota Makassar, kasus baru penderita tuberkulosis paru BTA (+) di Puskesmas dan Rumah Sakit tahun 2015 yaitu 1.928 penderita dari 2.600 perkiraan sasaran sehingga didapatkan Angka Penemuan Kasus Baru Tuberkulosis BTA (+) yaitu $73,76 \%$ (ditemukan 1.918 penderita dari 2.600 sasaran).(Kandou Manado et al., 2016)

Kasus tuberculosis paru harus diobati secara intensif selama 2 (dua) bulan dengan isoniazid, rifampicin, pyrazinamide and ethambutol diikuti oleh fase lanjutan dengan isoniazid dan rifampisin selama 4 (empat bulan) (D’Ambrosio et al., 2015) Gangguan fungsi hati yang disebabkan oleh obat anti tuberculosis dapat menyebabkan pengobatan dihentikan dan menimbulkan kerusakan hati. Hepatotoksis yang diinduksi oleh obat adalah merupakan efek samping yang dapat disebabkan oleh pengobatan tuberculosis yang terdiri dari isoniazid, rifampisin dan pirazinamid, ketiga obat tersebut efektif untuk menanggulangi tuberculosis dan WHO telah menyatakan bahwa ketiga jenis obat tesebut telah diteliti potensial memiliki kemampuan hepatotoksik(Choijamts, Batsyren and Orkhon, 2018)(Khadka et al., 2009)

Meningkatnya insiden tuberkulosis di negara kita, menyebabkan paparan pasien terhadap obat-obatan Antituberkulosis dan rifampisin merupakan bagian dari rejimen. Salah satu efek samping utama dari obat anti tuberculosis adalah hepatitis yang diinduksi oleh obat yang ditandai dengan peningkatan enzim hati dan bilirubin. Hepatotoksisitas biasanya idiosinkratik atau tergantung dosis. Rifampisin menyebabkan peningkatan sementara transaminase pada 10-20 persen orang dan ini tidak menjamin penyesuaian dosis obat. Jarang rifampisin dapat menyebabkan hepatitis berat dengan hiperbilirubinemia dan peningkatan SGOT dan SGPT dan pada beberapa pasien ini bisa berakibat fatal. rifampisin menyebabkan penyakit kuning klinis yang ditandai dengan hiperbilirubinemia tak terkonjugasi tanpa peningkatan enzim hati dan kejadian semacam itu sangat jarang.(Manigandan and Seshadri, 2016) 
Pengobatan TB, yang dinamakan Obat Anti Tuberkulosis (OAT) yang terdiri isoniazid, etambutol, pirazinamid, rifampicin dan streptomisin yang harus dikonsumsi selama 6-8 bulan. Akan tetapi, OAT memiliki efek samping terutama menggangu fungsi hati yang dapat dinilai melalui pemeriksaan kadar serum SGOT, SGPT dan bilirubin. Evaluasi fungsi hati dapat dilakukan beberapa pemeriksaan kontrol sebagai mencegah efek samping dari OAT di Indonesia adalah SGOT, SGPT dan bilirubin. Hasil penelitian di RSUP Prof DR. R.D. Kandou Manado periode Januari 2012-Desember 2014, penelitian observasional deskriptif dengan pendekatan potong lintang (cross sectional) jumlah sampel yang terpakai sebanyak 32 orang. Terjadi peningkatan kadar bilirubin total selama pengobatan OAT. Ditemukan sebesar (47\%) terjadi peningkatan kadar bilirubin total. Kadar bilirubin total meningkat lebih banyak pada pasien laki-laki. Peningkatan bilirubin total terjadi pada usia >35 tahun dan semakin meningkat seiring bertambahnya usia. Sedangkan, kadar bilirubin direk ditemukan sebanyak (56\%) terjadi peningkatan bilirubin direk. Kadar bilirubin indirek ditemukan normal pada (91\%).(Kandou Manado et al., 2016)

Cedera hati yang diinduksi obat adalah masalah yang meningkat signifikan pada pasien infeksi tuberculosis.(Choijamts, Batsyren and Orkhon, 2018) Hati memiliki peran sentral dalam metabolisme obat dan detoksifikasi, dan akibatnya rentan terhadap cedera. Patogenesis dan tipe cedera mulai dari adaptasi hepatik hingga cedera hepatoseluler.. Langkah-langkah sistematis untuk pencegahan dan pengelolaan cedera hati induksi obat TB direkomendasikan. (Saukkonen et al., 2006)

Rejimen untuk tuberculosis adalah dengan lini pertama OAT, terdiri dari obat Isoniazid (H), Etambutol (E), Pirazinamid (Z), Rifampicin (R) dan Streptomisin(S) yang harus diberikanselama 6 bulan, dengan pembagian dosis 2 bulan pertama kombinasi RHZE dan 4 bulan berikutnya kombinasi RH. Gangguan fungsi hati merupakan sebuah efek samping akibat penggunaan OATyang tersering dikeluhkan oleh pasien. Hal ini ,sering disebut Antituberculosis drug induced hepatotoxicity.(Ramappa and Aithal, 2013)(Abera, Cheneke and Abebe, 2015) Ketiga OAT yaitu isoniazid, rifampicin, dan pirazinamid merupakan tiga obat yang dapat menyebabkan hepato-toksitas, karena ketiganya dimetabolisme di hati. Tetapi, kedua OAT yaitu etambutol dan streptomisin tidak menyebabkan hepatotoksik.10 Evaluasi fungsi hati dapat dilakukan beberapa pemeriksaan kontrol sebagai mencegah efek samping dari OAT di Indonesia adalah SGOT, SGPT dan bilirubin.(Kandou Manado et al., 2016). Pengukuran SGOT, bilirubin, dan alkali fosfat merupakan metode pemeriksaan untuk memantau penyakit hati kronis, kolestasis, atau cedera hepatoseluler yang parah..(Saukkonen et al., 2006)

Sesuai dengan uji kerentanan obat (DST),obat yang paling efektif yaitu obat grup 1 harus dimasukkan dalam rejimen, dengan mempertimbangkan bahwa isoniazid, rifampisin/ rifabutin, dan pirazinamid adalah obat inti dan etambutol adalah obat pendamping. Streptomisin tidak lagi digunakan secara rutin. Obat suntik lini kedua hanya memiliki sifat membunuh namun tidak menghilangkan bakteri sehingga lini kedua merupakan obat yang kurang efektif.(Tiberi et al., 2017) 


\section{METODE}

Penelitian ini merupakan jenis penelitian analitik yaitu untuk mengetahui gambaran kadar bilirubin terhadap lama waktu konsumsi obat anti tuberkulosis (OAT) pada penderita tuberkulosis paru.

Sampel dalam penelitian ini adalah penderita Tuberkulosis Paru yang sedang menjalani pengobatan selama 2 bulan, 3 bulan, 4 bulan, dan 5 bulan di Puskesmas Jumpandang Baru dan Puskesmas Bara-Barayya dengan teknik pengambilan sampel purposive sampling.

Penderita Tuberkulosis yang mengonsumsi obat anti tuberkulosis (OAT) lini pertama, yang menjalani pengobatan selama 2 bulan, 3 bulan, 4 bulan dan 5 bulan. bersedia menandatangani informed consent.

Bahan yang digunakan dalam penelitian ini adalah serum dan kapas alkohol 70\%. Instrumen yang digunakan dalam penelitian ini dalam penelitian ini adalah tourniquet, tabung vakum merah (non antikoagulan), rak tabung, mikropipet $100 \mu \mathrm{l}$, tip kuning, pipet tetes, spoit $3 \mathrm{ml}$, aluminium foil, plester, tissue, box sample, sentifuge dan
Automatic Chemistry Analyzer. Data diperoleh dari hasil pembacaan alat dtuangkan dalam bentuk tabel sesuai dengan lamanya waktu konsumsi obat dibandingkan hasil pemeriksaan di bandingkan dengan nilai rujukan. Pengolahan data dalam bentuk persentase yang normal dan mengalami peningkatan kadar bilirubin dan hasil perhitungan disajikan dalam bentuk persentase. Analisis data dilakukan menggunakan rumus:

$\left(\%=\frac{f}{N} \times 100 \%\right)$

Keterangan Rumus :

$$
\begin{aligned}
& \%: \text { Persentasi Kejadian } \\
& \text { f : Frekuensi Kejadian } \\
& \text { N : Jumlah Sampel }
\end{aligned}
$$

\section{HASIL}

Berdasarkan hasil pemeriksaan 28 sampel diperoleh hasil sebagai berikut:

Tabel 1. Hasil Pemeriksaan Kadar Bilirubin pada Penderita Tuberkulosis Paru yang Menjalani Pengobatan Selama 2 Bulan

\begin{tabular}{cccccccc}
\hline No & Nama & $\begin{array}{c}\text { Jenis } \\
\text { Kelamin }\end{array}$ & $\begin{array}{c}\text { Umur } \\
(\text { tahun })\end{array}$ & $\begin{array}{c}\text { Bilirubin } \\
\text { Total } \\
(\mathrm{mg} / \mathrm{dl})\end{array}$ & $\begin{array}{c}\text { Bilirubin } \\
\text { direk } \\
(\mathrm{mg} / \mathrm{dl})\end{array}$ & $\begin{array}{c}\text { Bilirubin } \\
\text { indirek } \\
(\mathrm{mg} / \mathrm{dl})\end{array}$ & $\begin{array}{c}\text { Nilai rujukar } \\
(\mathrm{mg} / \mathrm{dl})\end{array}$ \\
\hline 1. & $\mathrm{A}$ & $\mathrm{L}$ & 24 & 0,47 & 0,12 & 0,35 & $\begin{array}{c}\text { Bil. Total: } \\
0,00-1,00\end{array}$ \\
2. & $\mathrm{B}$ & $\mathrm{P}$ & 60 & 0,90 & 0,52 & 0,38 & \\
3. & $\mathrm{C}$ & $\mathrm{L}$ & 31 & 0,58 & 0,24 & 0,34 & Bil.Direk \\
4. & $\mathrm{D}$ & $\mathrm{P}$ & 27 & 0,55 & 0,24 & 0,31 & $0,00-0,30$ \\
5. & $\mathrm{E}$ & $\mathrm{P}$ & 50 & 0,54 & 0,32 & 0,22 & \\
\end{tabular}




$\begin{array}{cccccccc}\text { 6. } & \mathrm{F} & \mathrm{P} & 53 & 0,53 & 0,27 & 0,26 & \begin{array}{c}\text { Bil. } \\ \text { Indirek: } \\ \text { 7. }\end{array} \\ & \mathrm{G} & \mathrm{P} & 59 & 0,92 & 0,09 & 0,83 & <1\end{array}$

Sumber. Data Primer, 2018

Berdasarkan tabel 1, diketahui bahwa kadar bilirubin total dan bilirubin indirek pada semua sampel tidak terjadi peningkatan, kadar bilirubin direk yang mengalami peningkatan sebanyak 2 sampel dan yang normal sebanyak 5 sampel.

Tabel 2. Hasil Pemeriksaan Kadar Bilirubin pada Penderita Tuberkulosis Paru yang Menjalani Pengobatan Selama 3 Bulan

\begin{tabular}{|c|c|c|c|c|c|c|c|}
\hline No & Nama & Jenis Kelamir & $\begin{array}{l}\text { Umur } \\
\text { (tahun) }\end{array}$ & $\begin{array}{l}\text { Bilirubin Tot } \varepsilon \\
(\mathrm{mg} / \mathrm{dl})\end{array}$ & $\begin{array}{l}\text { Bilirubin } \\
\text { Direk } \\
\text { (mg/dl) }\end{array}$ & $\begin{array}{l}\text { Bilirubir } \\
\text { Indirek } \\
\text { (mg/dl) }\end{array}$ & $\begin{array}{c}\text { Nilai } \\
\text { Rujukan } \\
\text { (mg/dl) }\end{array}$ \\
\hline 1. & $\mathrm{H}$ & $\mathrm{L}$ & 49 & 0,55 & 0,29 & 0,26 & $\begin{array}{l}\text { Bil. Total: } \\
0.00-1.00\end{array}$ \\
\hline 2. & I & $\mathrm{L}$ & 33 & 0,34 & 0,11 & 0,23 & \\
\hline 3. & $\mathbf{J}$ & $\mathrm{P}$ & 18 & 0,55 & 0,28 & 0,27 & \\
\hline 4. & $\mathrm{~K}$ & $\mathrm{~L}$ & 63 & 1,04 & 0,51 & 0,53 & $\begin{array}{l}\text { Bil.Direk: } \\
0,00-0,30\end{array}$ \\
\hline 5. & $\mathrm{~L}$ & $\mathrm{P}$ & 28 & 1,66 & 0,58 & 1,08 & \\
\hline 6. & M & $\mathrm{P}$ & 38 & 0,38 & 0,11 & 0,27 & $\begin{array}{l}\text { Bil. Indirek: } \\
<1\end{array}$ \\
\hline 7. & $\mathrm{~N}$ & $\mathrm{~L}$ & 47 & 0,33 & 0,09 & 0,24 & \\
\hline
\end{tabular}

Sumber. Data Primer, 2018

Berdasarkan tabel 2, diketahui bahwa kadar bilirubin total dan bilirubin direk mengalami peningkatan masing-masing sebanyak 2 sampel dan yang normal sebanyak 5 sampel serta kadar bilirubin indirek dengan peningkatan sebanyak 1 sampel dan yang normal sebanyak 6 sampel.

Tabel 3. Hasil Pemeriksaan Kadar Bilirubin pada Penderita Tuberkulosis Paru yang Menjalani Pengobatan Selama 4 Bulan

\begin{tabular}{lcccllll}
\hline No & Nama & $\begin{array}{c}\text { Jenis } \\
\text { Kelamin }\end{array}$ & $\begin{array}{l}\text { Umur } \\
\text { (tahun) }\end{array}$ & $\begin{array}{l}\text { Bilirubin total Bilirubin direk } \\
(\mathrm{mg} / \mathrm{dl})\end{array}$ & $\begin{array}{l}\text { Bilirubin } \\
\text { indirek } \\
(\mathrm{mg} / \mathrm{dl})\end{array}$ & $\begin{array}{l}\text { Nilai rujukan } \\
(\mathrm{mg} / \mathrm{dl})\end{array}$ \\
\hline 1. & $\mathrm{O}$ & $\mathrm{P}$ & 35 & 0,63 & 0,30 & 0,33 & $\begin{array}{l}\text { Bil. Total: } \\
0,00-1,00\end{array}$ \\
2. & $\mathrm{P}$ & $\mathrm{P}$ & 79 & 0,26 & 0,09 & 0,17 &
\end{tabular}




$\begin{array}{llllllll}\text { 3. } & \mathrm{Q} & \mathrm{L} & 51 & 0,46 & 0,09 & 0,37 & \begin{array}{l}\text { Bil.Direk: } \\ 0,00-0,30\end{array} \\ \text { 4. } & \mathrm{R} & \mathrm{L} & 39 & 0,60 & 0,29 & 0,31 & \\ \text { 5. } & \mathrm{S} & \mathrm{L} & 61 & 0,78 & 0,44 & 0,34 & \begin{array}{l}\text { Bil. Indirek: } \\ \text { ( }\end{array} \\ \text { 6. } & \mathrm{T} & \mathrm{P} & 40 & 0,77 & 0,28 & 0,49 & \\ \text { 7. } & \mathrm{U} & \mathrm{L} & 50 & 2,37 & 1,11 & 1,26 & \end{array}$

Sumber. Data Primer, 2018

Berdasarkan tabel 3, diketahui bahwa kadar bilirubin total dan bilirubin indirek yang mengalami peningkatan masingmasing sebanyak 1 sampel dan yang

normal 6 sampel serta kadar bilirubin direk yang mengalami peningkatan sebanyak 2 sampel dan yang normal sebanyak 5 sampel.

Tabel 4. Hasil Pemeriksaan Kadar Bilirubin pada Penderita Tuberkulosis Paru yang Menjalani Pengobatan Selama 5 Bulan

\begin{tabular}{|c|c|c|c|c|c|c|c|}
\hline No & Nama & $\begin{array}{l}\text { Jenis } \\
\text { Kelamin }\end{array}$ & $\begin{array}{l}\text { Umur } \\
\text { (tahun) }\end{array}$ & $\begin{array}{l}\text { Bilirubin } \\
\text { Total } \\
(\mathrm{mg} / \mathrm{dl})\end{array}$ & $\begin{array}{l}\text { Bilirubin } \\
\text { Direk } \\
(\mathrm{mg} / \mathrm{dl})\end{array}$ & $\begin{array}{l}\text { Bilirubin } \\
\text { Indirek } \\
(\mathrm{mg} / \mathrm{dl})\end{array}$ & $\begin{array}{l}\text { Nilai } \\
\text { Rujukan } \\
\text { (mg/dl) }\end{array}$ \\
\hline 1. & $\mathrm{~V}$ & $\mathrm{P}$ & 63 & 0,83 & 0,39 & 0,44 & $\begin{array}{l}\text { Bil. Total: } \\
0,00-1,00\end{array}$ \\
\hline 2. & W & $\mathrm{L}$ & 28 & 0,53 & 0,14 & 0,39 & \\
\hline 3. & $X$ & $\mathrm{~L}$ & 38 & 0,27 & 0,09 & 0,18 & $\begin{array}{l}\text { Bil.Direk: } \\
0,00-0,30\end{array}$ \\
\hline 4. & $\mathrm{Y}$ & $\mathrm{L}$ & 38 & 0,33 & 0,11 & 0,22 & \\
\hline 5. & Z & $\mathrm{L}$ & 45 & 0,38 & 0,10 & 0,28 & Bil. \\
\hline 6. & A1 & $\mathrm{L}$ & 22 & 0,27 & 0,09 & 0,18 & $\begin{array}{l}\text { Indirek: } \\
<1\end{array}$ \\
\hline 7. & $\mathrm{~A} 2$ & $\mathrm{~L}$ & 33 & 0,31 & 0,10 & 0,21 & \\
\hline
\end{tabular}

Sumber. Data Primer, 2018

Berdasarkan tabel 4, diketahui bahwa kadar bilirubin total dan bilirubin indirek pada semua sampel tidak terjadi peningkatan, kadar bilirubin direk yang mengalami peningkatan sebanyak 1 sampel dan yang normal sebanyak 6 sampel.
Selanjutnya, pengolahan data dilakukan dengan menghitung nilai persentase yaitu dengan melihat hasil normal dan tinggi dalam bentuk persentase. 
Tabel 5. Distribusi Kadar Bilirubin Total terhadap Lama Waktu Konsumsi Obat Anti Tuberkulosis Penderita Tuberkulosis Paru

\begin{tabular}{llllllll}
\hline \multirow{2}{*}{ No. } & Masa & \multicolumn{2}{l}{ Meningkat } & \multicolumn{2}{l}{ Normal } & \multicolumn{3}{c}{ Total } \\
& Pengobatan & Jumlah & $\%$ & Jumlah & $\%$ & Jumlah & $\%$ \\
\hline 1. & 2 bulan & 0 & $0 \%$ & 7 & $100 \%$ & 7 & $100 \%$ \\
2. & 3 bulan & 2 & $28,57 \%$ & 5 & $71,43 \%$ & 7 & $100 \%$ \\
3. & 4 bulan & 1 & $14,29 \%$ & 6 & $85,71 \%$ & 7 & $100 \%$ \\
4. & 5 bulan & 0 & $0 \%$ & 7 & $100 \%$ & 7 & $100 \%$ \\
\hline
\end{tabular}

Sumber. Data Primer, 2018

Berdasarkan tabel 5, diketahui bahwa kadar bilirubin total terhadap lama waktu konsumsi obat anti tuberkulosis pada penderita tuberkulosis paru terjadi peningkatan bulan ketiga sebesar 28,57\% dan bulan keempat sebesar 14,29\%, bulan kedua dan kelima normal (tidak mengalami peningkatan) sebesar $100 \%$.

Tabel 6. Distribusi Kadar Bilirubin Direk terhadap Lama Waktu Konsumsi Obat Anti Tuberkulosis Penderita Tuberkulosis Paru

\begin{tabular}{llllllll}
\hline \multirow{2}{*}{ No. } & Masa & \multicolumn{2}{l}{ Meningkat } & Normal & \multicolumn{2}{c}{ Total } \\
& Pengobatan & Jumlah & $\%$ & Jumlah & $\%$ & Jumlah & $\%$ \\
\hline 1. & 2 bulan & 2 & $28,57 \%$ & 5 & $71,43 \%$ & 7 & $100 \%$ \\
2. & 3 bulan & 2 & $28,57 \%$ & 5 & $71,43 \%$ & 7 & $100 \%$ \\
3. & 4 bulan & 2 & $28,57 \%$ & 5 & $71,43 \%$ & 7 & $100 \%$ \\
4. & 5 bulan & 1 & $14,29 \%$ & 6 & $85,71 \% 7$ & $100 \%$ \\
\hline
\end{tabular}

Sumber. Data Primer, 2018

Berdasarkan tabel 6, diketahui bahwa kadar bilirubin direk terhadap lama waktu konsumsi obat anti tuberkulosis pada penderita tuberkulosis paru bulan kedua sampai dengan bulan keempat terjadi peningkatan sebesar $28,57 \%$ dan bulan kelima $14,29 \%$.

Tabel 7 Distribusi Kadar Bilirubin Indirek terhadap Lama Waktu Konsumsi Obat Anti Tuberkulosis Penderita Tuberkulosis Paru

\begin{tabular}{llllllll}
\hline \multirow{2}{*}{ No. } & Masa & \multicolumn{2}{l}{ Meningkat } & Normal & \multicolumn{3}{c}{ Total } \\
& Pengobatan & Jumlah & $\%$ & Jumlah & $\%$ & Jumlah & $\%$ \\
\hline 1. & 2 bulan & 0 & $0 \%$ & 7 & $100 \%$ & 7 & $100 \%$ \\
2. & 3 bulan & 1 & $14,29 \%$ & 6 & $85,71 \%$ & 7 & $100 \%$ \\
3. & 4 bulan & 1 & $14,29 \%$ & 6 & $85,71 \%$ & 7 & $100 \%$ \\
4. & 5 bulan & 0 & $0 \%$ & 7 & $100 \%$ & 7 & $100 \%$ \\
\hline
\end{tabular}

Sumber. Data Primer, 2018

Berdasarkan tabel 7, diketahui bahwa kadar bilirubin indirek terhadap lama waktu konsumsi obat anti tuberkulosis pada penderita tuberkulosis paru bulan ketiga dan bulan keempat terjadi peningkatan sebesar $14,29 \%$, bulan kedua 
dan kelima normal (tidak terjadi peningkatan) sebesar $100 \%$.

Tabel 8 Distribusi Peningkatan Kadar Biliribin Total, Bilirubin Direk, dan Bilirubin Indirek Selama Pengobatan

\begin{tabular}{llll}
\hline No & Bilirubin & Jumlah & Persentase \\
\hline 1 & Bilirubin Total & 3 & $10.71 \%$ \\
2 & Bilirubin Direk & 7 & $25 \%$ \\
3 & Bilirubin Indirek & 2 & $7,14 \%$ \\
\hline
\end{tabular}

Sumber. Data Primer,2018

Berdasarkan tabel 8, diketahui bahwa dari ketiga hasil pemeriksaan kadar bilirubin, dapat diketahui bahwa peningkatan kadar bilirubin total sebesar 10,71\%, kadar bilirubin direk yang paling banyak mengalami kenaikan $25 \%$ selama pengobatan. Sedangkan kadar bilirubin indirek tidak mengalami peningkatan yang cukup tinggi yaitu sebesar $(7,14 \%)$ selama pengobatan.

\section{PEMBAHASAN}

Pada hasil penelitian yang telah dideskripsikan sebelumnya, diperoleh bahwa dari Subjek penelitian berasal dari pasien Puskesmas Jumpandang Baru sebanyak 17 orang dan Puskesmas BaraBarayya sebanyak 11 orang. Pada penelitian ini diketahui jumlah subjek masing-masing berjumlah 7 pada pengobatan tuberkulosis selama 2 bulan, 3 bulan, 4 bulan, dan 5 bulan.

Didapatkan hasil analisis kadar bilirubin terhadap lama waktu konsumsi obat anti tuberkulosis pada penderita tuberkulosis paru yaitu kadar bilirubin total pada bulan kedua dan kelima normal $(100 \%)$ dan terjadi peningkatan pada bulan ketiga $(28,57 \%)$ dan bulan keempat $(14,29 \%)$, kadar bilirubin direk pada bulan kedua sampai dengan bulan keempat terjadi peningkatan $(28,57 \%)$ dan bulan kelima $(14,29 \%)$ serta kadar bilirubin indirek bulan kedua dan bulan kelima normal (100\%) dan terjadi peningkatan pada bulan ketiga dan bulan keempat $(14,29 \%)$.
Dan dari ketiga hasil pemeriksaan kadar bilirubin, dapat diketahui bahwa peningkatan kadar bilirubin total sebesar $10,71 \%$, kadar bilirubin direk yang paling banyak mengalami kenaikan $25 \%$ selama pengobatan. Penelitian sebelumnya yang dilakukan oleh Wahyuningsih (2014) menemukan sebesar $36,4 \%$ pasien tuberkulosis paru mengalami peningkatan kadar bilirubin direk.

Sedangkan kadar bilirubin indirek tidak mengalami peningkatan yang cukup tinggi yaitu sebesar $(7,14 \%)$ selama pengobatan. Kadar bilirubin indirek ditemukan sebesar 9\% pasien Tuberkulosis Paru yang mengalami peningkatan kadar bilirubin indirek. Peningkatan kadar bilirubin indirek hanya terjadi pada kondisi seperti hemolisis, sindrom Gilbert, sindrom Crigler-najjar, inefektif eritropoesis, dan reabsorbsi dari hematoma yang besar.(Kandou Manado et al., 2016)

Berbagai penelitian telah dilakukan untuk mengetahui efek samping dari obat tuberkulosis yang dikonsumsi. Walaupun terdapat berbagai penuntun penegakkan diagnosis untuk cedera hati imbas obat, tetapi parameter peningkatan kadar bilirubin masih merupakan salah satu kriteria.

Hasil penelitian dari 114 sampel darah dikumpulkan untuk analisis enzim hati. Ditemukan bahwa di antara114 pasien ATT; 41 pasien $(35,0 \%)$ memiliki parameter abnormal dengan peningkatan 
kadar bilirubin serum, tingkat AST dan tingkat ALT. Dari 114 kasus, peningkatan kadar bilirubin total yang ditandai (> 5,0mg / dl) ditemukan pada $15(13,0 \%)$ dan peningkatan kadar bilirubin (1,1-5,0 mg / dl) ditemukan pada 25 (22,0\%) pasien. sementara $74(65,0 \%)$ pasien ditemukan memiliki kadar bilirubin normal.(Khadka et al., 2009)

Faktor kemiskinan, kekurangan gizi, konsumsi alkohol, buta huruf orang dan sistem manajemen kesehatan yang buruk. Oleh karena itu, untuk pengobatan TB, dengan rejimen anti tuberkulosis, pengujian laboratorium dasar dan sistem pemantauan harus diadopsi sebelum memulai pengobatan yang mungkin membantu mengurangi hepatotoksisitas yang diinduksi obat pada pasien. (Khadka et al., 2009) .Bilirubin bebas berikatan dengan albumin plasma dan mengalir dalam darah menuju hati. Bilirubin bebas dianggap tidak terkonjugasi karena walaupun berikatan dengan albumin, pengikatannya bersifat reversibel (bilirubin indirek). Beberapa senyawa seperti antibiotika dan obat-obatan bersaing dengan bilirubin untuk mengadakan ikatan dengan albumin, sehingga dapat mempunyai pengaruh klinis (Gusti, 2017).

Setelah berada di hati, bilirubin dibebaskan dari albumin dan, karena bilirubin bebas bersifat larut dalam lemak, bilirubin tersebut mudah masuk ke dalam hepatosit. Setelah berada dalam hepatosit, bilirubin dengan cepat berikatan dengan zat lain, biasanya asam glukuronat, dan di tempat ini dianggap terkonjugasi. Bilirubin terkonjugasi bersifat larut air dan tidak larut dalam lemak (bilirubin direk).

Pada penelitian sebelumnya mengenai Kadar SGOT dan SGPT pada Pasien Tuberkulosis Paru selama 2 Bulan Berjalannya Pemberian Obat Anti
Tuberkulosis Kombinasi Dosis Tetap, perubahan kadar SGOT sebelum dan setelah diberikan Obat Anti Tuberkulosis menunjukkan bahwa terdapat pengaruh pemberian Obat Anti Tuberkulosis (OAT) kombinasi dosis tetap terhadap kadar SGOT dan SGPT(Sayamber, 2017) dengan peningkatan kadar sebesar 55\%. Hal ini menunjukkan Obat Anti Tuberkulosis (OAT) dapat mempengaruhi fungsi hati yang dibuktikan dengan hasil penelitian yang dilakukan bahwa terdapat peningkatan pada kadar bilirubin penderita tuberkulosis paru.(Nelwan, Stella Palar and Lombo, 2014)

Ketika penderita tuberkulosis mengonsumsi obat anti tuberkulosis (OAT), obat di absorpsi di usus, didistribusikan melalui aliran darah ke organ hati, dan di metabolisme di dalam hati. Pada saat metabolisme dalam hati maka obat isoniazid akan mengalami proses asetilasi yang menghasilkan metabolit aktif. Kombinasi obat rifampisin dan pirazinamid akan menyebabkan terjadinya peningkatan metabolisme dari isoniazid sehingga meningkatkan hidrazin dan metabolit toksik lainnya yang akan menyebabkan kerusakan sel di hati (hepatotoksik).

Disaat obat dikonsumsi secara terus menerus, maka akan berpengaruh pada kadar bilirubinnya. Hal ini menyebabkan bilirubin indirek mengendap di dalam darah akibat banyaknya bilirubin indirek yang tidak berikatan dengan albumin untuk proses konjugasi. Sedangkan untuk bilirubin direk, kerusakan sel hati menyebabkan bilirubin tidak dapat diekskresikan keluar dari empedu menuju usus sehingga akan masuk kembali dan terabsobsi ke dalam aliran darah. Oleh karena itu, dari hasil pemeriksaan kadar bilirubin, maka akan terjadi peningkatan bilirubin direk dan bilirubin indirek. 
Dapat dilihat dari hasil penelitian yang dilakukan, pada setiap bulan pengobatan pasti ada yang mengalami kenaikan kadar bilirubin, meskipun hanya sedikit yang mengalami kenaikan dengan rerata sebanyak 1 sampel atau 2 sampel yang mengalaminya. Kebanyakan hasil penelitian kadar bilirubin normal, hal ini dikarenakan adanya faktor - faktor yang dapat mempengaruhi hasil.

Jenis kelamin, perempuan tampaknya berisiko lebih besar terhadap efek samping obat dibandingkan dengan pria. Selain masalah obat, karakteristik pasien berhubungan dengan peningkatan resiko peningkatan kejadian efek samping obat.

Penyakit, penanganan obat dapat diubah pada pasien yang mengalami gangguan metabolisme seperti gangguan kerusakan hati. Penyakit yang membutuhkan terapi obat ganda memiliki resiko terkena efek samping obat. Penyakit degeneratif dapat mengubah penanganan farmakokinetik obat, sensitivitas jaringan, atau respon terhadap suatu obat. Artinya, penyakit bisa mengubah penyerapan obat, metabolisme, eliminasi, dan respon tubuh terhadap obat.

Perbedaan farmakokinetik, obat memiliki risiko efek samping pada saat terjadi perbedaan farmakokinetik dalam tubuh. Perbedaan ini antara lain ada peningkatan toksisitas dari obat karena faktor genetik (misalnya perbedaan dalam aktivitas enzim) dan adanya pengaruh lingkungan (misalnya asupan alkohol tinggi).

Adapun kelemahan dari penelitian ini adalah tidak diketahui data kadar bilirubin pasien sebelum pengobatan sehingga tidak dapat dipastikan bahwa hasil penelitian yang mengalami peningkatan disebabkan oleh obat anti tuberkulosis. Dalam proses penelitian ini masih banyak faktor-faktor yang dapat mempengaruhi hasil yang belum dapat terkendali secara ketat, misalnya seperti penggolongan kategori umur dan kategori lain yang dapat mempengaruhi peningkatan kadar bilirubin. Selain itu, jumlah sampel yang diperiksa pun terbatas untuk memperkuat hasil penelitian.

\section{KESIMPULAN}

Gambaran kadar bilirubin terhadap lama waktu konsumsi obat anti tuberkulosis (OAT) pada penderita tuberkulosis paru yaitu kadar bilirubin total normal pada bulan kedua dan kelima, terjadi peningkatan pada bulan ketiga dan keempat. Kadar bilirubin direk pada bulan kedua sampai dengan bulan kelima terjadi peningkatan serta kadar bilirubin indirek bulan kedua dan bulan kelima normal dan terjadi peningkatan pada bulan ketiga dan bulan keempat. Dengan demikian pemeriksaan kadar bilirubin total, direk dan indirek perlu dilakukan sebagai salah satu tes pemantauan fungsi hati penderita tuberkulosis yang menjalani pengobatan.

\section{SARAN}

Berdasarkan kesimpulan diatas, maka penulis dapat memberikan saran yaitu :

1. Dilakukan penelitian lanjutan untuk menganalisis fungsi hati dengan pemeriksaan atau metode yang lebih spesifik dan menambah jumlah sampel pemeriksaan.

2. Untuk klinisi sebaiknya terhadap penderita tuberkulosis diperiksa fungsi hatinya termasuk kadar bilirubin sebelum pengobatan dimulai dan setiap bulan pengobatan sebagai kontrol sehingga efek samping OAT dapat cepat diketahui dan ditangani dengan baik. 


\section{UCAPAN TERIMA KASIH}

Terima kasih kepada semua pihak yang telah membantu dalam penelitian ini.

\section{DAFTAR PUSTAKA}

Abera, W., Cheneke, W. and Abebe, G. (2015) 'Incidence of antituberculosis-drug-induced hepatotoxicity and associated risk factors among tuberculosis patients in Dawro Zone, South Ethiopia: A cohort study', International Journal of Mycobacteriology. Asian African Society for Mycobacteriology, 5(1), pp. 14-20. doi: 10.1016/j.ijmyco.2015.10.002.

Choijamts, G., Batsyren, C. and Orkhon, B. (2018) 'Role of Liv . 52 DS Tablets as a Hepatoprotective Agent in Tuberculosis Patients Receiving Antitubercular Drugs: A Double Blind Placebo Controlled Study', 5, pp. 1-9.

D'Ambrosio, L. et al. (2015) 'New anti-tuberculosis drugs and regimens: 2015 update', ERJ Open Research, 1(1), pp. 0001002015. doi: 10.1183/23120541.00010-2015.

Kandou Manado, R. D. et al. (2016) 'Gambaran kadar bilirubin pasien tuberkulosis paru selama pengobatan di RSUP Prof', Jurnal e-Clinic, 4(1).

Kementerian Kesehatan RI (2018)

'Pusat Data dan Informasi

Tuberkulosis', Infodatin

Tuberkulosis. doi: 2442-7659.

Khadka, J. et al. (2009) 'THE STUDY

OF DRUG INDUCED

HEPATOTOXICITY IN ATT

PATIENTS ATTENDING IN

NATIONAL TUBERCULOSIS

CENTER IN BHAKTAPUR',
(2), pp. 17-21.

Manigandan, G. and Seshadri, M. S. (2016) 'Biphasic effect of rifampicin on bilirubin-a Case Report', Journal of Clinical and Diagnostic Research, 10(4), pp. OD14-OD15. doi: 10.7860/JCDR/2016/18040.7614.

Nelwan, A. R. P., Stella Palar and Lombo, J. C. M. (2014) 'Jurnal eClinic (eCl), Volume 2, Nomor 3, November 2014', 2(November).

Ramappa, V. and Aithal, G. P. (2013) 'Hepatotoxicity Related to Antituberculosis Drugs: Mechanisms and Management', Journal of Clinical and Experimental Hepatology. Elsevier Ltd, 3(1), pp. 37-49. doi: 10.1016/j.jceh.2012.12.001.

Saukkonen, J. J. et al. (2006) 'An official ATS statement: hepatotoxicity of antituberculosis therapy.', American journal of respiratory and critical care medicine, 174(8), pp. 935-52. doi: $\quad$ 10.1164/rccm.2005101666ST.

Sayamber, A. (2017) 'A study of changes in SGPT and SGOT over time the patients of drug induced hepatitis taking antitubercular drugs', 3(August), pp. 58-64.

‘TB Global Report 2016 WHO’ (no date).

Tiberi, S. et al. (2017) 'Classifying new anti-tuberculosis drugs: rationale and future perspectives', International Journal of Infectious Diseases, 56, pp. 181184. doi: 10.1016/j.ijid.2016.10.026. 